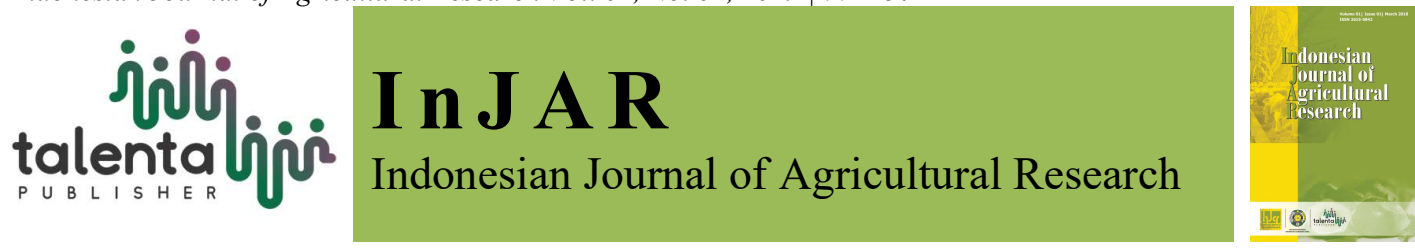

\title{
Identification of Milkfish Supply Chain in PT XYZ at Semarang City, Central Java Province
}

\author{
M Mustopa Romdhon*, Asmarani, and Melli \\ Departement of Social Economic, Faculty of Agriculture, Bengkulu University, Bengkulu, Indonesia
}

\begin{abstract}
Bandeng Presto is one of the typical foods of Semarang City, one of the famous milkfish processing industries is PT XYZ. This study aims to identify milkfish supply chains at PT XYZ in Semarang City. The collection of primary and secondary data was carried out in January-February 2019, which was used in describing the supply chain flow. The method of data analysis uses descriptive qualitative. The results obtained are 2 patterns of supply chain flow, the flow I pattern consists of companies - suppliers as well as farmers and flow patterns II consisting of companies - suppliers - farmers. The activities of each pattern are explained in the flow of product, information, and financial.
\end{abstract}

Keywords: management, milkfish, supply chain

Received 28 July 2019 | Revised 11 September 2019| Accepted 19 September 2019

\section{Introduction}

The aquaculture sector in Central Java Province consists of nine types of cultivation, including fish pond cultivation. Famous commodities from fish pond fisheries include milkfish, shrimp and crabs. One of the cities that has the highest number of aquaculture production is Semarang City, with a value of 2,516.85 tons [1]. The value of GDP (Gross Domestic Product) from the fisheries sector amounts to $84,407.70$ billion, this value is quite large compared to the forestry sector which only has a GDP value of 20,209.20 billion [2].

One of the fishery products which is widely cultivated and used as the main raw product for the processing industry is milkfish (Chanos chanos) Indonesia [3]. In Semarang, this is one of the main raw products in the manufacture of the famous cuisine namely Bandeng Presto. Bandeng Presto is one of the souvenirs that are hunted by tourists both local and foreign when visiting Semarang City. Many industries or post-harvest companies that process bandeng presto in Semarang City, one of which is PT XYZ.

\footnotetext{
*Corresponding author at: Department of Agricultural Socio-Economics, Faculty of Agriculture, University of Bengkulu, Jl. WR. Supratman Kandang Limun, Bengkulu, Indonesia

E-mail address: m.romdhon@unib.ac.id
} 
Fisheries products have a short lifespan and a high level of vulnerability to weather. Its availability and sustainability should be important notice. Thereby it needs special handling, packaging, and distribution. To maintain product quality, effective and efficient supply chain management is needed. One of the analytical frameworks used to improve fisheries distribution is the Supply Chain Management (SCM) principle. Supply chains are to emphasized product flow and transformation, information and financial flows from the raw product stages to the last users [4]. The application of SCM has proven to be able to increase efficiency and effectiveness in the process of distributing fishery products from fish pond farmers to consumers [5]. SCM is useful in creating quality, inexpensive, and supply commodities that are by following consumer needs (demand), both domestic and export markets. To maintain product quality, effective and efficient of their availability and sustainability supply chain management is needed to know. The research tries to identify the supply Chain Management at PT XYZ Semarang City, Central Java Province”.

\section{Research Method}

The determination of the location of the study was purposive sampling was at PT XYZ located on Jl. Pandanaran No.57 Semarang. This research was conducted in January - February 2019. The next sample is determined by the snowball sampling method where samples were based on information from PT XYZ by following the milkfish supply flow starting from suppliers to farmers was obtained data of two suppliers and three farmers. The method used in this study was qualitative to process primary and secondary data. The primary data include such as product price, production, and product quality etc, while the secondary data were financial record (profit, cost, etc) from statement, dan marketing activities (days of delivery, marketing actors, market scope etc). The data were descriptively explanation to determine the flow of the supply chain.

\section{Results and Discussion}

\subsection{Respondent Identity}

Milkfish supply chain flow at PT XYZ is a flow that starts from the company to the farmers. Chains that move in the flow are the company, suppliers, and farmers. The milkfish supply chain flow has a different product (product), information and financial activities. The results of the study show that there are two supply chain flows. This happens because partner suppliers are acting as farmers and working with other farmers in supplying milkfish every day. Chain flow moves from upstream to downstream or vice versa because the flow of activity goes back and forth from each

supply chain actor. Each pattern of milkfish supply chain flow is explained from upstream to downstream as follows : 


\subsection{Supply Chain Pattern Flow I}

Supply chains are dynamic and have a flow of information, products, and financial. The main objective of the supply chain is to meet customer satisfaction and to make a profit. This supply chain activity starts from the order submitted by the customer and ends after the customer's satisfaction is fulfilled [6]. The pattern of supply chain I flow is the flow of milkfish originating from companies to suppliers as a farmer.

\subsection{Supply Chain Flow Pattern II}

The pattern of supply chain flow which is the second chain flow comes from the company than to partner suppliers ending with farmers. The differentiation of the flow pattern I with the flow pattern II. The supplier flow pattern I also act as a chain of farmers but in the flow pattern II, the supplier cooperates with other farmers to supply milkfish. This flow tends to be more complex than the flow pattern I, the pattern of supply chain flow relates to more chains in each flow so that it can be seen the difference in supply chain performance. Also, production size of the pattern I least the production size of the pattern I. It was needed supply from others to fill the given production size. Supply chain flows move from upstream to downstream or vice versa. The pattern of supply chain flow has a product, information, and financial activities. Activities from upstream to downstream that occur in the chain flow are the same as activities from downstream to upstream.

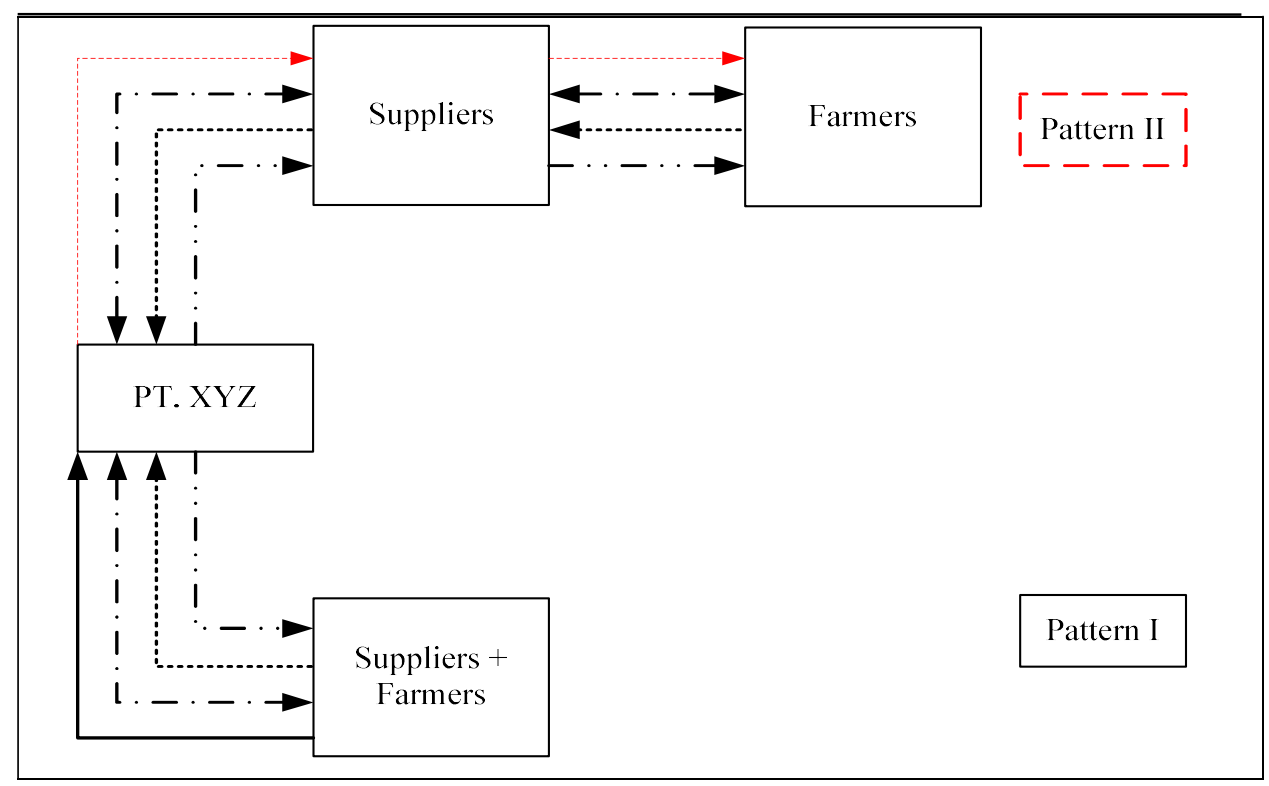

Information:

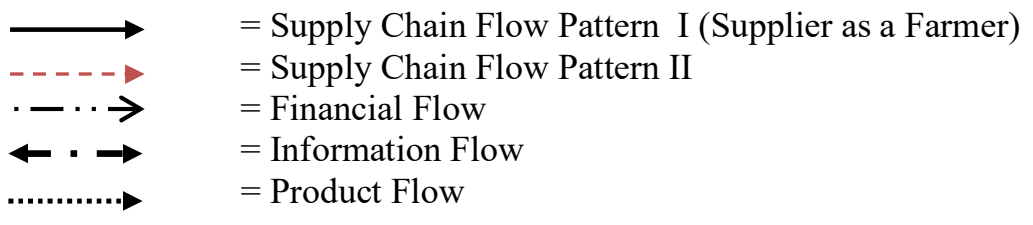

Figure 1. Flow Pattern of Milkfish Supply Chains at PT XYZ 


\subsection{Product Flow}

The flow of product flows in two directions both from upstream to downstream and vice versa. Product flows from upstream to downstream from raw product to final products [7]. The flow obtained from the results of the study is also the same as the theory stated that the flow of product comes from upstream to downstream and vice versa. The flow of raw product for milkfish at PT $\mathrm{XYZ}$ as follows :

\subsubsection{Supply chain product flow pattern I}

Activities from the procurement of raw products starts from supplier selection, evaluates supplier performance, purchases raw products and supporting components, monitors supply risk and fosters and maintains relationships with suppliers [7]. The first product flow from suppliers or vice versa to PT XYZ. The first product flow from suppliers + farmers to PT XYZ or vice versa. The pattern of flow chain I product can be seen in the picture as follows :

Tabel 1. Supply Chain Product Flow Pattern I

\begin{tabular}{ccll}
\hline No & \multicolumn{1}{c}{ Supply } & \multicolumn{1}{c}{ Indicator } & \multicolumn{1}{c}{ Information } \\
\hline 1 & Farmers + & - The number of harvests & Indicator affecting to \\
& the company
\end{tabular}

Source: Processed from Primary Data 2019

\subsubsection{Supply chain product flow pattern II}

Product flow comes from farmers - suppliers - PT XYZ and the three of them influence each other. This flow pattern uses more marketing institutions in the sale of raw milkfish. The disadvantage of this pattern is that the product will tend to reach the company for a longer time about 24 hours compare to standard under 14 hours. The risk was price change (18\% to $20 \%$ ) at any time according to market price of milkfish. In the opinion of [8] that in milkfish distribution channels of two marketing channels that have few marketing institutions involved are the most efficient because marketing costs are smaller and efficient compare to others pattern. The chain product flow pattern II can be seen in the picture as follows. 
Tabel 2. Supply Chain Product Flow Pattern II

\begin{tabular}{ccll}
\hline No & Supply & \multicolumn{1}{c}{ Indicator } & \multicolumn{1}{c}{ Information } \\
\hline 1 & Farmers & $\begin{array}{l}\text { - The amount of harvests } \\
\text { - Transportation }\end{array}$ & $\begin{array}{l}\text { Indicator affecting to the } \\
\text { suppliers }\end{array}$ \\
2 & Suppliers & $\begin{array}{l}\text { - The amount of inventory } \\
\text { - Sorting of raw product } \\
\end{array}$ & $\begin{array}{l}\text { Indicator affecting to the } \\
\text { company }\end{array}$ \\
3 & $\begin{array}{l}\text { The } \\
\text { company }\end{array}$ & $\begin{array}{l}\text { - The supply of raw products and auxiliary } \\
\text { - Procurement of raw products }\end{array}$ & $\begin{array}{l}\text { When raw products do not } \\
\text { match the criteria, a return } \\
\text { to the suppliers occurs. }\end{array}$ \\
\hline
\end{tabular}

Source: Processed from Primary Data 2019

\subsection{Information Flow}

Information [7] flows from upstream to downstream and vice versa, including the criteria for raw products, order quantities, prices up to trends. Empirically, the flow of information at PT XYZ Semarang is as follows :

\subsubsection{Supply chain information flow pattern I}

Information flow from PT XYZ - suppliers + farmers or vice versa, both influence each other. The first information flow from PT XYZ to suppliers or vice versa. The activity of the company when ordering milkfish to suppliers always informs the criteria of milkfish desired by the company. The pattern of information flow in flow pattern I :

Table 3. Supply Chain Information Flow Pattern I

\begin{tabular}{|c|c|c|c|}
\hline No & Supply & Indicator & Information \\
\hline 1 & Farmers + Suppliers & $\begin{array}{l}\text { - Several things including the } \\
\text { number of harvests } \\
\text { - Criteria for raw products } \\
\text { - Prices } \\
\text { - Time of ordering }\end{array}$ & $\begin{array}{l}\text { Indicator affecting to the } \\
\text { company }\end{array}$ \\
\hline 2 & The company & $\begin{array}{l}\text { - The criteria of raw products } \\
\text { - Inventory } \\
\text { - Shipping cycle } \\
\text { - Ordering method }\end{array}$ & \\
\hline
\end{tabular}

Source: Processed from Primary Data 2019

\subsubsection{Supply chain information flow pattern II}

In pattern II, information flows from the company than to the last supplier marketing agency from the farmer. Information flow that occurs from upstream to downstream or vice versa. The following are things that affect the flow of information in the flow pattern II. 
Table 4. Supply Chain Information Flow Pattern II

\begin{tabular}{|c|c|c|c|}
\hline No & Supply & Indicator & Information \\
\hline 1 & Farmers & $\begin{array}{l}\text { - The amount of harvests } \\
\text { - Price Fluctuation } \\
\text { - Transportation }\end{array}$ & $\begin{array}{l}\text { Indicator affecting to the } \\
\text { suppliers }\end{array}$ \\
\hline 2 & Suppliers & $\begin{array}{l}\text { - Inventory } \\
\text { - Sorting of raw product }\end{array}$ & $\begin{array}{l}\text { Indicator affecting to the } \\
\text { company }\end{array}$ \\
\hline 3 & The company & $\begin{array}{l}\text { - The criteria of raw products } \\
\text { - Inventories } \\
\text { - Procurement of raw products } \\
\text { - Return }\end{array}$ & $\begin{array}{l}\text { When raw products do not } \\
\text { match the criteria, a return } \\
\text { to the suppliers occurs. }\end{array}$ \\
\hline
\end{tabular}

Source: Processed from Primary Data 2019

\subsection{Financial Flow}

According to [7] cash flows from downstream to upstream and vice versa as a consequence of receipt of goods. It also includes credit card information, credit terms, payment schedules in determining ownership and delivery. It can be seen from the financial flow of the milkfish supply chain flow at PT XYZ as follows :

\subsubsection{Supply chain financial flow pattern I}

The first financial flow comes from PT XYZ to suppliers as a farmer or vice versa. The things that affect the two chains are the payment terms. Next is the financial flow in the flow pattern I :

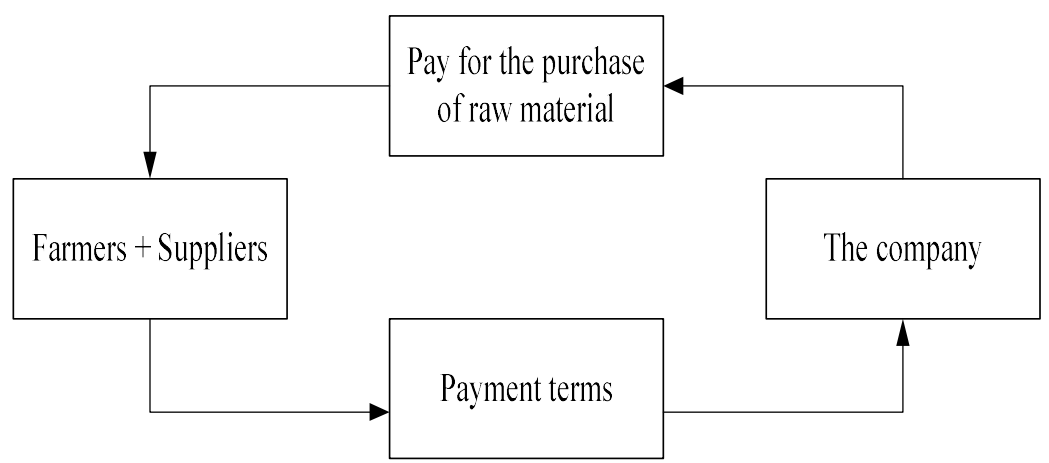

Figure 2. Supply Chain Financial Flow Pattern I at PT XYZ

The company makes payments once a week, direct payments to suppliers of milkfish without intermediaries. This flow does not exchange money from suppliers to farmers because in this case, the chain acts as a supplier and also a farmer. The flow pattern I has been said to be good because the company is never late in making payments and suppliers are also able to handle problems that occur during the process of sending raw products.

\subsubsection{Supply chain financial flow pattern II}

The flow pattern in pattern II still comes from the company - suppliers - farmers. The company acts as the first chain to make payments to suppliers, this applies the same as flow pattern I. Distinguishing flow I pattern with flow pattern II that is in this pattern suppliers work together 
with other milkfish farmers and not from their farms. The supplier's marketing margin value is an average of IDR 3000 - 4000/kg. the purchase price from farmers ranges from IDR 21,000 -IDR 22,000 . [8] state that it is proven the higher the value of marketing margins, the lower part the farmers get. Farmers buy seeds in a range of IDR 100 -IDR 400; Workers who work are paid a daily wage of IDR 80,000 , with working hours starting at 05.00 WIB -11.00 WIB. Here is a picture of the flow pattern II :

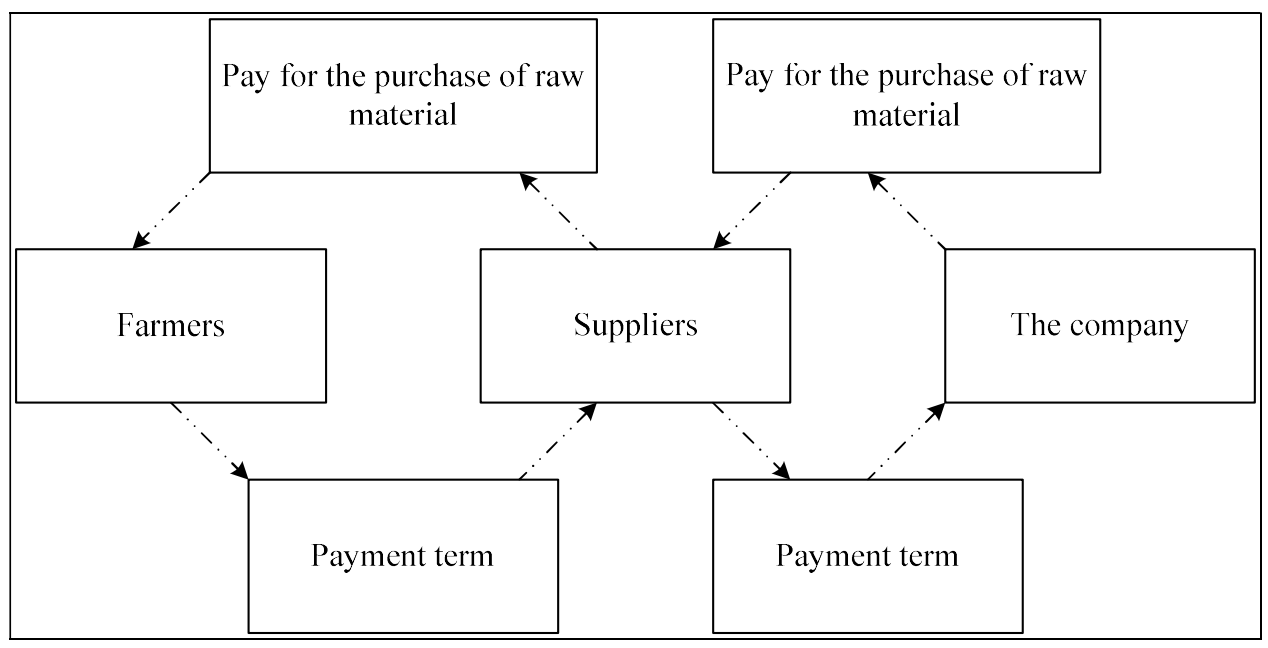

Figure 2. Supply Chain Financial Flow Pattern II at PT XYZ

\section{Conclusion and Recommendation}

\subsection{Conclusion}

The flow of the milkfish supply chain at PT XYZ has 2 flow patterns. The flow pattern I flow from the chain of companies and suppliers who also acts as farmers. The flow pattern II flows from the company chain to the supplier then the farmer. Each pattern has a flow of information, product flow, and financial flow. Information flow moves from upstream to downstream or vice versa, and product flow moves from upstream to downstream, while financial flow moves from downstream to upstream.

\subsection{Recommendation}

For companies, it is expected to choose suppliers who also become farmers. Because in the chain flow pattern to meet needs can be directly related to the chain, so if you need unexpected requests you can immediately work together without having to wait longer to get the desired raw product. It can take advantage of time and costs effectively and efficiently. It is expected to guide suppliers to avoid mistakes in the delivery of raw products.

For suppliers, it is expected to be able to maintain its performance to fulfill the demand or order from the milkfish processing industry. 
For farmers, it is expected to be able to maintain the performance that has been done to fulfill orders or requests from suppliers. Farmers are expected to be able to work with several supervisory institutions in the process of milkfish cultivation because it can affect the sustainability of the cultivation process and income received.

\section{REFERENCES}

[1] Dinas Kelautan dan Perikanan Provinsi Jawa Tengah, Produksi Perikanan Budidaya Menurut Jenis Budidaya Prov. Jawa Tengah Tahun 2016, Semarang: Dinas Kelautan dan Perikanan Provinsi Jawa Tengah, 2016.

[2] Badan Pusat Statistik Kota Semarang, Semarang Dalam Angka Tahun 2017, Semarang: Badan Pusat Statistik, 2017.

[3] R. B. Jakaria, "Analisis supply chain manajemen guna optimalisasi distribusi ikan bandeng," in Prosiding Seminar Nasional Inovasi Teknologi Universitas Nusantara PGRI, Kediri, Feb 2017.

[4] C. Yolandika, "Analisis supply chain management brokoli CV. Yan's fruits and Vegetable di Kabupaten Bandung Barat," Tesis, Institut Pertanian Bogor, Kota Bogor, 2016.

[5] A. S. Slamet, Marimin, Y. Arkeman, and F. Udin, "Studi peningkatan kinerja manajemen rantai pasok sayuran dataran tinggi di Jawa Barat, Agritech, vol. 31, no. 1, pp. 60-70, 2011.

[6] Marimin and N. Maghfiroh, Aplikasi Teknik Pengambilan Keputusan dalam Manajemen Rantai Pasok. Bogor: IPB Press, 2010.

[7] I, N. Pujawan, Supply Chain Management. Edisi Kedua. Surabaya: Guna Widya, 2010.

[8] Nurdiana and Marhawati, "Analisis pemasaran ikan bandeng di Desa Pitue Kecamatan Ma'arung Kabupaten Pangkep," Jurnal Ekonomi dan Pendidikan, vol. 1, no. 1, pp. 64-72, 2018. 